\title{
SPECC1/PDGFRB Fusion Gene
}

National Cancer Institute

\section{Source}

National Cancer Institute. SPECC1/PD GFRB Fusion Gene. NCI Thesaurus. Code C99833.

A fusion gene that results from a chromosomal translocation $t(5 ; 17)(q 33 ; p 11.2)$ which fuses the 5' portion of the SPECC1 gene to the 3' portion of the PDGFRB gene. This rearrangement is associated with juvenile myelomonocytic leukemia. 